\title{
Atomic force microscopy with fractal studies of temperature induced changes in the surface topography of polymeric materials
}

\author{
Tomasz Rydzkowski ${ }^{1, *)}$, Slawomir Kulesza ${ }^{2)}$, Miroslaw Bramowicz ${ }^{3)}$, Iwona Michalska-Pożoga ${ }^{1)}$ \\ DOI: dx.doi.org/10.14314/polimery.2020.1.4
}

\begin{abstract}
Changes in the surface topography of polymeric materials can be analyzed to find the correspondence between observed surface features and specific external factors that might also influence physical and functional properties of the investigated material. In this work, atomic force microscopy (AFM) measurements were carried out to investigate the thermal changes in the surface topography as well as in the inner structure of the low density polyethylene (LDPE) samples subjected to 10 recirculations (rLDPE). For better assessment, fractal analysis and AFM results were additionally compared to DSC tests results.
\end{abstract}

Keywords: temperature, surface topography, polymeric materials, atomic force microscopy, fractal analysis, differential scanning calorimetry, low density polyethylene, recirculation.

\section{Zastosowanie mikroskopii sił atomowych i analizy fraktalnej do badania wpływu temperatury na topografię powierzchni materiałów polimerowych}

\begin{abstract}
Streszczenie: Analiza zmian topografii powierzchni materiałów polimerowych pozwala wyznaczyć zależności między obserwowanymi cechami powierzchni a określonymi czynnikami zewnętrznymi, które mogą wpływać na właściwości fizyczne i funkcjonalne badanego materiału. W niniejszej pracy metodą mikroskopii sił atomowych (AFM) oceniano zmiany termiczne topografii powierzchni, a także wewnętrznej struktury próbek polietylenu małej gęstości (LDPE) poddanych 10-krotnej recyrkulacji (rLDPE). Wyniki AFM i analizy fraktalnej porównywano z wynikami badań metodą różnicowej kalorymetrii skaningowej (DSC).
\end{abstract}

Słowa kluczowe: temperatura, topografia powierzchni, materiały polimerowe, mikroskopia sił atomowych, analiza fraktalna, różnicowa kalorymetria skaningowa, polietylen małej gęstości, recyrkulacja.

Surface topography of solids and particularly polymeric materials, formed by cooling from the melt, results from processes occurring in various parts of their structure. Subsequent development and treatment procedures also contribute to the final specific shape of the surface. According to Mainsah [1], any engineering process leaves its fingerprint, thereby detailed characterization of the surfaces modified by various external factors, such as: temperature, stress, radiation, magnetization, etc., is the key issue for the emergence of new technolo-

\footnotetext{
1) Koszalin University of Technology, Department of Mechanical Engineering, Raclawicka 15-17, 75-620 Koszalin, Poland.

2) University of Warmia and Mazury in Olsztyn, Faculty of Mathematics and Computer Science, Sloneczna 54, 10-710 Olsztyn, Poland.

3) University of Warmia and Mazury in Olsztyn, Faculty of Technical Sciences, Oczapowskiego 11, 10-719 Olsztyn, Poland.

*) Author for correspondence;

e-mail: tomasz.rydzkowski@tu.koszalin.pl
}

gies and miniaturization concerning the ability to control physical as well as functional properties of materials [2-5].

Atomic force microscopy (AFM) is an increasingly popular surface technique. It is gaining wider and wider applications. It is used to study the structure of a wide variety of materials, it is widely used in metallurgy and ceramics, it is tested by a variety of biological tissues (including cancer) in medicine and even a variety of biological material in forensic examinations [6-9]. The AFM technique is also used to examine polymers, but mainly for simple surface analysis and properties or chemical reactions $[10,11]$. In this material, the authors will analyze the results of polymer surface analysis using fractal analysis. Literature studies indicate that it is probably the first attempt to apply fractal analysis to surface measurements of polymers obtained by AFM. This research is aimed at presenting results of a study on temperature induced changes in the surface topography of polymeric materials. 


\section{EXPERIMENTAL PART}

\section{Methodology}

Surface topography of the polymer sample was studied by means of atomic force microscopy and fractal analysis, while it's inner structure was investigated using differential scanning calorimetry (DSC). Sample pills (2-5 $\mathrm{mm}$ high and $5 \mathrm{~mm}$ wide) were pressed from low density polyethylene recyclat (rLDPE - Malen E FABS) after 10 cycles of polymer recirculation. After several processing cycles, the material is more sensitive to temperature changes. Multimode 8 instrument with Nanoscope $\mathrm{V}$ controller (Bruker) and ScanAsyst-Air scanning tip (Bruker) was used to carry out AFM measurements that works in a proprietary PeakForce Tapping QNM mode. Changes in surface heights were investigated by means of statistical analysis and fractal geometry. It is worth noting that recently there is a growing interest in the latter method for detailed characterization of surface features over a wide range of wavelengths. It does not require previous selection of a proper scale of a measurement, hence neglecting the dependence of statistical parameters on the scan size [1, 12-18]. Probe tip scanned $256 \times 256$ points over $10 \times 10 \mu \mathrm{m}^{2}$ sample areas of polymers under the study maintained at temperatures from 20 to $60{ }^{\circ} \mathrm{C}$ that increased every $10{ }^{\circ} \mathrm{C}$. In addition, the PeakForce QNM mode also enables us to measure (not shown) tip-surface adhesion forces, reduced Young's moduli, energy dissipations and sample deformations.

In the beginning, AFM data in the form of sets of equidistant height samples were plane fitted to remove a second order surface bow exhibiting stationary surface referred to as the residual surface. Prior to the structure function (SF), fractal parameters were derived in a twostep procedure involving computation of the areal autocorrelation function (AACF). Even though the method is basically devoted to three-dimensional structures, it actually deals with averaged height profiles which is much simpler and numerically feasible. AACF data was also used for estimation of anisotropy ratio being the measure of a surface texture anisotropy. Suitable examples on comparative analyses of various fractal approaches have been reported in literature [17-23].

\section{Statistical analysis}

Distribution of sample heights on the surface of solids can be characterized employing spatial statistics defined in PN-EN ISO 25178-6:2011 standard [21] and it varies with the scan size and scan resolution. Hence, any comparison of obtained results can be made when particular measurement conditions are met. Main statistical characteristics explored throughout this paper are: arithmetic mean height $S_{a}$ and root-mean-square height $S_{q}$. The former, i.e. the average of the absolute heights in the measured area, is defined as follows:

$$
S_{a}=\frac{1}{M N} \sum_{k=0}^{M-1} \sum_{l=0}^{N-1}\left|z\left(k_{k}, y_{l}\right)\right|
$$

where: $M, N$ - the numbers of scan steps along each scan direction, $z\left(x_{k^{\prime}} y_{l}\right)$ - the height of a surface at a point with given coordinates.

Likewise, the root mean squared of height samples in the measured area is given by the formula:

$$
S_{q}=\sqrt{\frac{1}{M N} \sum_{k=0}^{M-1} \sum_{l=0}^{N-1}\left[z\left(k_{k}, y_{l}\right)\right]^{2}}
$$

Note, however, that these two parameters introduce inevitable ambiguity of the description since different surfaces might result in identical $S_{a}$ and $S_{q}$ values.

\section{Fractal analysis}

Fractal analysis provides coherent, multiscale description of geometrical shapes that extends over a wide range of scale lengths, at least several orders of magnitude. According to Mandelbrot [22], fractal is a self-similar structure which can be reproduced by multiple replications of its basic pattern in a proper scale. On the other hand, fractal dimension $D$ used for composite description of geometrical shapes defines both the scaling exponent of the power-law dependence and relative amplitude of roughness at different wavelengths. The fractal dimension depends on signal amplitude and its frequency.

Surfaces of solids can be described in a variety of ways, for example using: (i) statistical parameters derived from height samples taken in a given order, (ii) geometrical measures oriented toward specific patterns of clusters, (iii) characteristics of a surface relief. Alternatively, one may use areal auto covariance function $R(\tau)$ defined as an average product of a given signal without constant component and its lagged copy [1]:

$$
R\left(\tau_{x^{\prime}} \tau_{\mathrm{y}}\right)=\left\langle(z(x, y)-\langle z\rangle) \cdot\left(z\left(x+\tau_{x^{\prime}} y+\tau_{\mathrm{y}}\right)-\langle z)\right)\right\rangle
$$

where $\langle\ldots$.$\rangle means spatial average.$

Analysis of a 3-dimensional plot of this function gives insight into predominant surface lay, its directional periodicity, and the degree of its self-similarity. Moreover, AACF also serves as a starting point for computation of the structure function

$$
S(\tau)=2\left[S_{q}^{2}-R(\tau)\right]
$$

Log-log plot of $S(\tau)$ follows linear dependence for $\tau \ll \tau_{c}$ (Fig. 1) according to the power-law equation in the form:

$$
S(\tau)=\Lambda^{2(D-1)} \tau^{2(2-D)}
$$

where: $\Lambda$ - the surface topothesy, $\tau_{c}-$ the corner frequency. 
a)

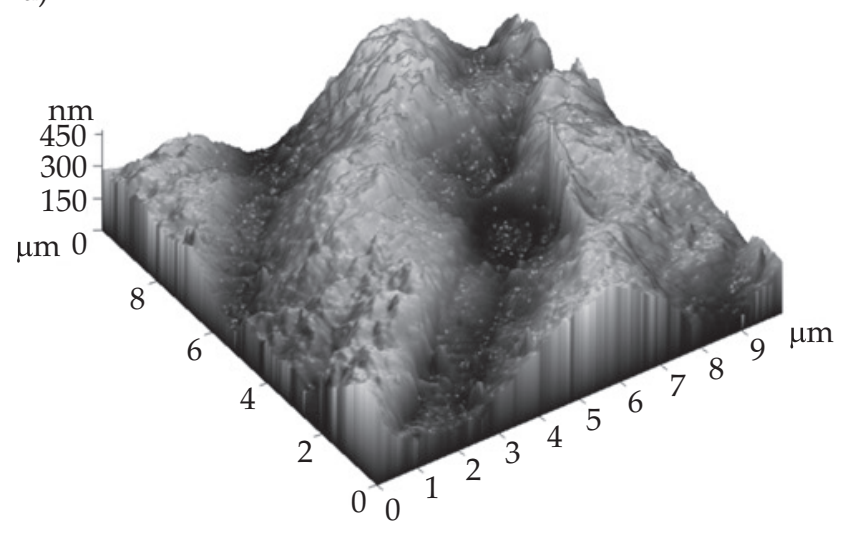

b)

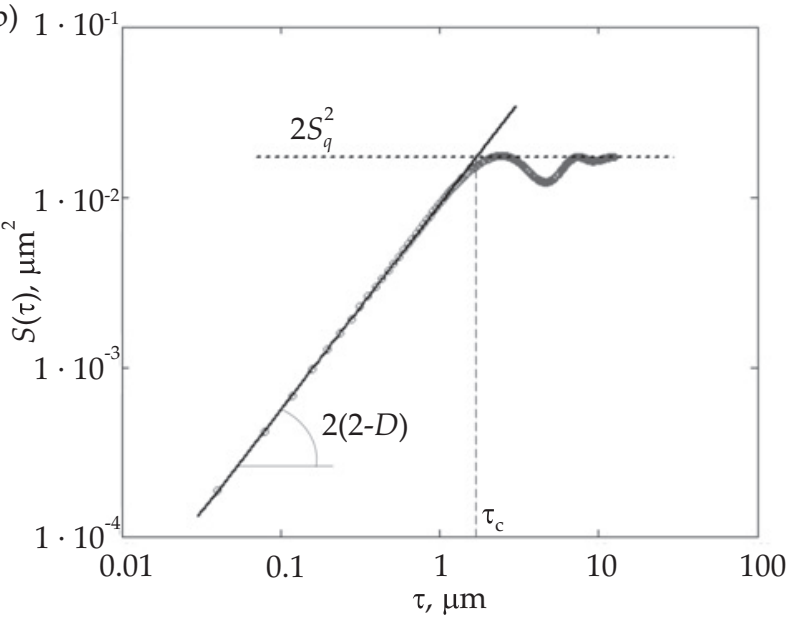

Fig. 1. LDPE polymer after 10 cycles of a recirculation process: a) AFM image, b) spatially-averaged profile of its structure function $S(\tau)$

The topothesy is defined as a distance between neighboring points on the surface inclined at an angle of $1 \mathrm{rad}$, so it usually takes extremely small values. On the other hand, the corner frequency establishes characteristics wavelength beyond which the power-law dependence turns into damped oscillation that asymptotically approach $2 S_{q}^{2}$.

Structure function can be also expressed in terms of the so-called pseudo-topothesy $K$, equal to the first term in Eq. (5). According to [21], pseudo-topothesy is given by the following formula:

$$
K=\frac{\pi G^{2(D-1)}}{2 \Gamma(5-2 \mathrm{D}) \sin [\pi(2-D)]}
$$

where: $\Gamma$ - the Euler's function, $G$ - scale-dependent constant.

a)

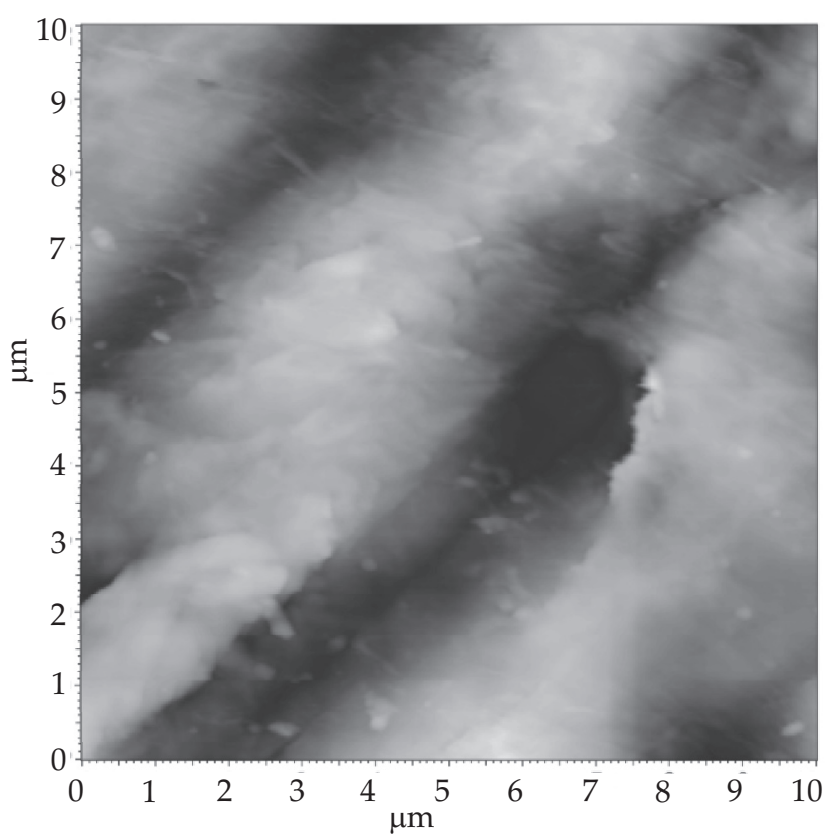

Previously published results [23-26] demonstrate that $K$ is closely related to the distribution of a stray magnetic field from magnetic domains, enabling the structure of the domains to be analyzed with the fractal geometry.

\section{Estimation of the surface anisotropy}

Given function $R(\tau)$ computed all around the AFM image (Fig. 2), it is possible to estimate the surface texture anisotropy. Presented procedure requires that directions of extreme decays of AACF be established at first, as in Fig. 2b. Compared to Fig. 2a, these directions very well agree with predominant lay pattern, hence they are assumed equivalent to main axes of the surface lay anisotropy $a_{1}$, and $a_{2}$.

b)

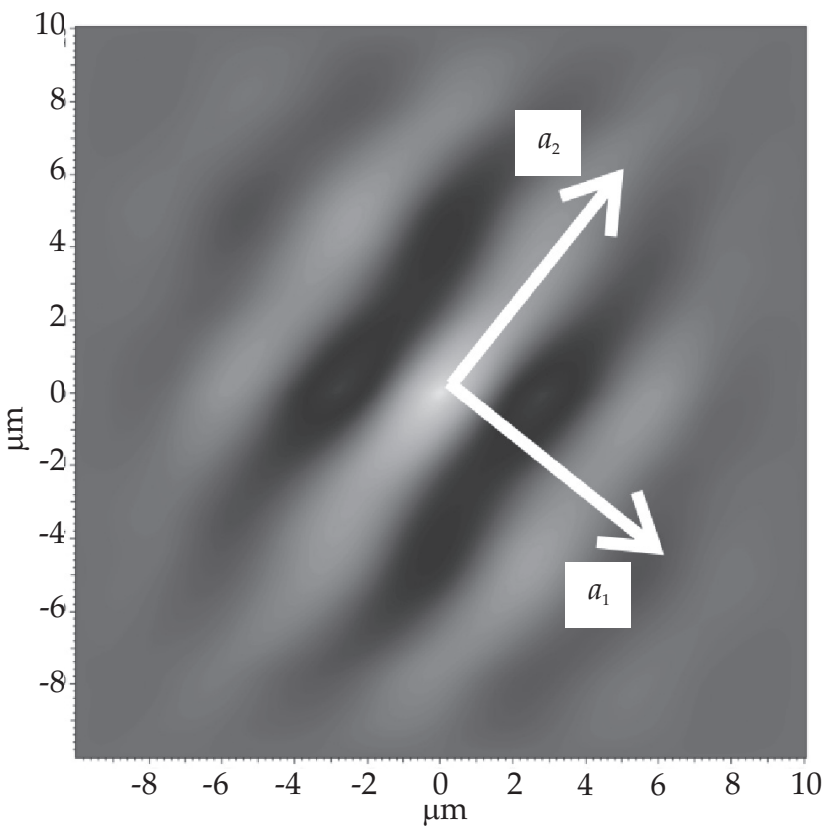

Fig. 2. Polymeric material after a tenfold recirculation process: a) AFM image of surface topography, b) map of its autocorrelation function $R(\tau)$ with main axes of the surface anisotropy $\left(a_{1}, a_{2}\right)$ 

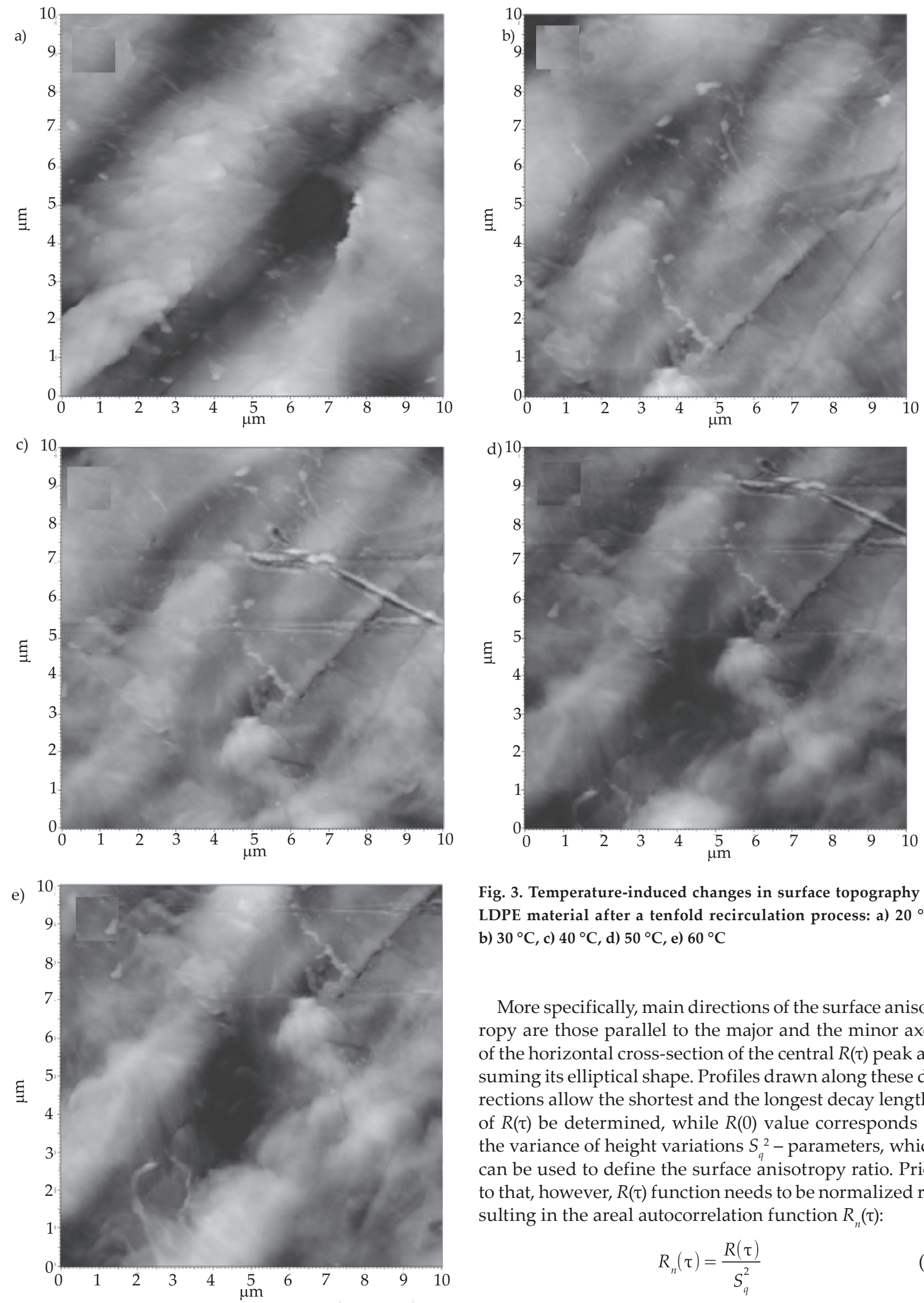

Fig. 3. Temperature-induced changes in surface topography of LDPE material after a tenfold recirculation process: a) $20^{\circ} \mathrm{C}$, b) $30^{\circ} \mathrm{C}$, c) $40^{\circ} \mathrm{C}$, d) $50^{\circ} \mathrm{C}$, e) $60^{\circ} \mathrm{C}$

More specifically, main directions of the surface anisotropy are those parallel to the major and the minor axes of the horizontal cross-section of the central $R(\tau)$ peak assuming its elliptical shape. Profiles drawn along these directions allow the shortest and the longest decay lengths of $R(\tau)$ be determined, while $R(0)$ value corresponds to the variance of height variations $S_{q}{ }^{2}$ - parameters, which can be used to define the surface anisotropy ratio. Prior to that, however, $R(\tau)$ function needs to be normalized resulting in the areal autocorrelation function $R_{n}(\tau)$ :

$$
R_{n}(\tau)=\frac{R(\tau)}{S_{q}^{2}}
$$


The ratio of extreme $\tau_{a 1}$ and $\tau_{a 2}$ lengths, along which $R_{n}(\tau)$ decays from 1.0 down to 0.2 is referred to as the surface anisotropy ratio $S_{t r}$ :

$$
S_{t r}=\left.\frac{\tau_{a 1}}{\tau_{a 2}}\right|_{R_{n}=1 \rightarrow 0.2}
$$

Surfaces with $S_{t r}$ larger than 0.5 are considered to be isotropic, those with $S_{t r}$ in the range from 0.3 to 0.5 are thought to be anisotropic, whereas those with $S_{t r}$ less than 0.3 are considered highly anisotropic [27].

\section{Differential scanning calorimetry}

In order to confirm results obtained by AFM, additional measurements were carried out using differential scanning calorimetry (DSC). DSC relies on the measurement of the difference in the amount of heat flux supplied to the sample $\Phi_{S}$ and reference material $\Phi_{R}$ to study changes in their physical properties:

$$
\Delta \Phi=\Phi_{\mathrm{S}}-\Phi_{\mathrm{R}}
$$

In a power-compensated DSC, the sample and reference are heated by separate heaters, and it is the difference in thermal power required to maintain them at the same temperature that is actually measured. What is also important, temperature $T$ of specimens is increased linearly as a function of time $t$ with an arbitrary heating rate [28]:

$$
\beta=\frac{\Delta T}{\Delta t}
$$

DSC is frequently used in multiple applications for example: phase analysis, calorimetric studies of phase transitions and chemical reactions, measurements of specific heat of materials, determination of chemical composition and chemical purity of materials, determination of kinetic parameters of various reactions, etc. The advantage of this method among others is that a small sample mass will suffice, and that the heating rate can be adjusted in a wide range from a fraction up to several hundreds of deg per minute. Samples were taken from the outer thin layer. Under the study a sample is enclosed in a highpressure pan designed for thermoanalysis, which is usually made of aluminum, ceramics, platinum, copper or gold. Choice of a proper pan is very important, since it strongly affects induced thermal effect and might affect the obtained results [29-31].

DSC measurements were carried out using DSC822e STARe instrument (Mettler Toledo). Measurement settings were as follows: temperature range $T=25-160{ }^{\circ} \mathrm{C}$, heating rate $\beta=2 \mathrm{deg} / \mathrm{min}$, mass of the sample $m_{s}=8 \mathrm{mg}$, mass of the pan $m_{p}=48.8 \mathrm{mg}$. Sample was closed in an aluminum pan with a $0.04 \mathrm{~cm}^{3}$ pin. Mass of the sample was established using an analytical balance (XS 105 from Mettler Toledo) with $0.01 \mathrm{mg}$ accuracy. The measurement procedure complied with PN-EN ISO 11357:2009 [32].

\section{RESULTS AND DISCUSSION}

Figure 3 shows substantial changes in topographical images of the polymeric material under study caused by increasing temperature. Figure 4 shows that average surface profile measured at $30^{\circ} \mathrm{C}$ is ca. $2 \mu \mathrm{m}$ shifted compared to that at $20^{\circ} \mathrm{C}$, and substantial decrease in surface roughness expressed by $S_{q}$ and $S_{a}$ occurs (Fig. 5).

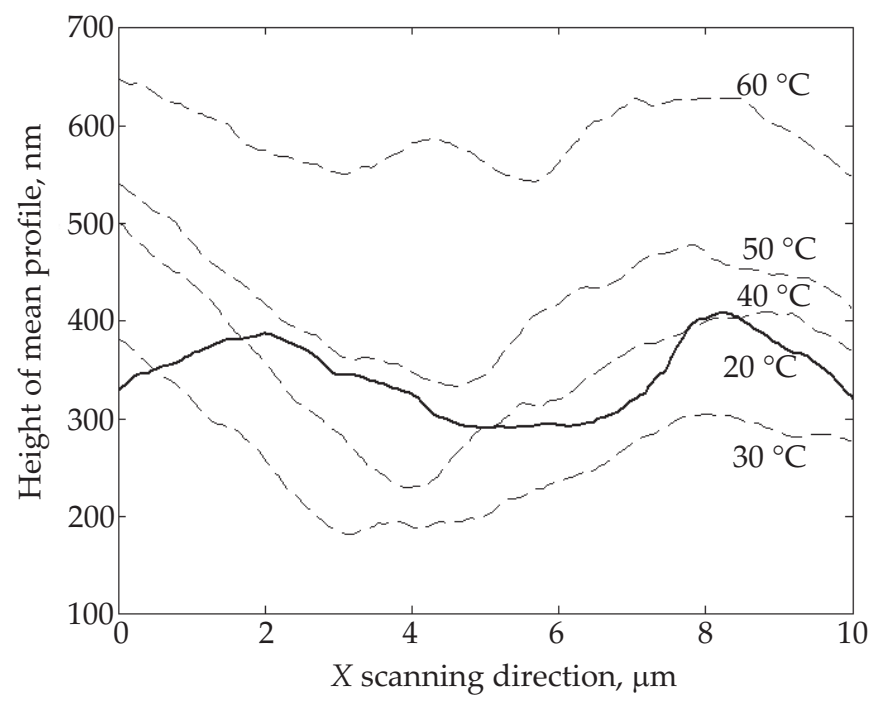

Fig. 4. Changes in the mean surface profile of LDPE sample after a tenfold recirculation process

This is probably caused by a single $4.3 \mu \mathrm{m}$ long microcrack that occurred due to thermal stresses inside the material. As the temperature was raised to $40{ }^{\circ} \mathrm{C}$, another two micro fractures appeared: the first one $1.7 \mu \mathrm{m}$ and the second one $3.3 \mu \mathrm{m}$ long. Observed microcracks do not extend with temperature, although they move horizontally due to increasing plasticization of the material. As shown in Fig. 4, increasing temperature also affects the mean height of the AFM profile, which goes up from $330 \mathrm{~nm}$ at $20^{\circ} \mathrm{C}$ to about $650 \mathrm{~nm}$ at $60^{\circ} \mathrm{C}$, probably due to thermal expansion of the material under study.

\section{Fractal analysis}

Figure 6 shows that the obtained fractal parameters: fractal dimension $D$, topothesy $\Lambda$, and corner frequency $\tau_{c^{\prime}}$ also demonstrate changes in geometrical structure of studied polymers as a function of temperature. According to previous studies, fractal dimension depends on surface height variations and surface periodicity, however, results presented in Fig. 6 suggest its strong, but nonmonotonical dependence on the temperature. In the beginning, fractal dimension $D$ gradually increases from $20{ }^{\circ} \mathrm{C}$ to $50{ }^{\circ} \mathrm{C}$, and sharply drops afterwards. Observed changes in $D$ are likely due to the devitrification process that relies on mixing parts of amorphous phase with those of crystalline ones in the material. Since changes begin when $D$ peaks at around $50{ }^{\circ} \mathrm{C}$, hence this temperature is referred to as the devitrification temperature. 
a)

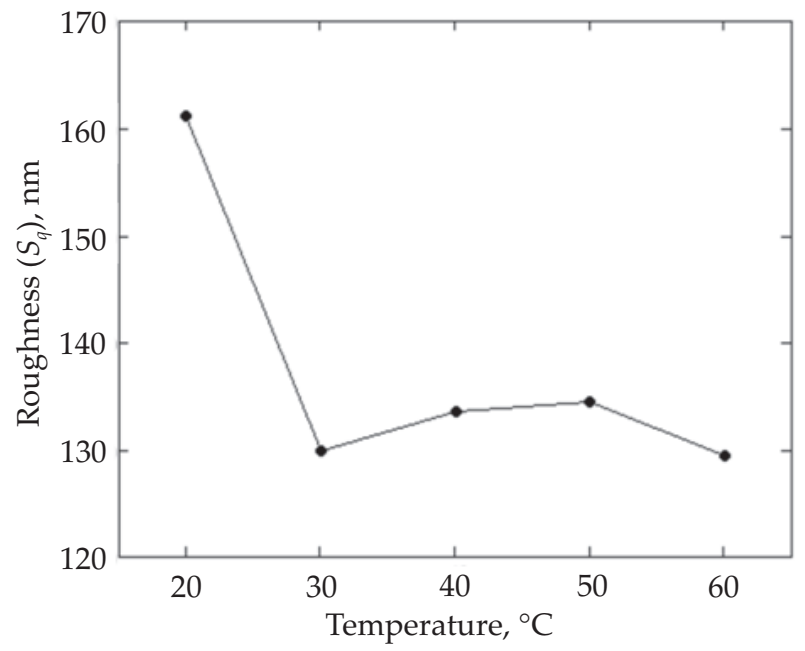

b)

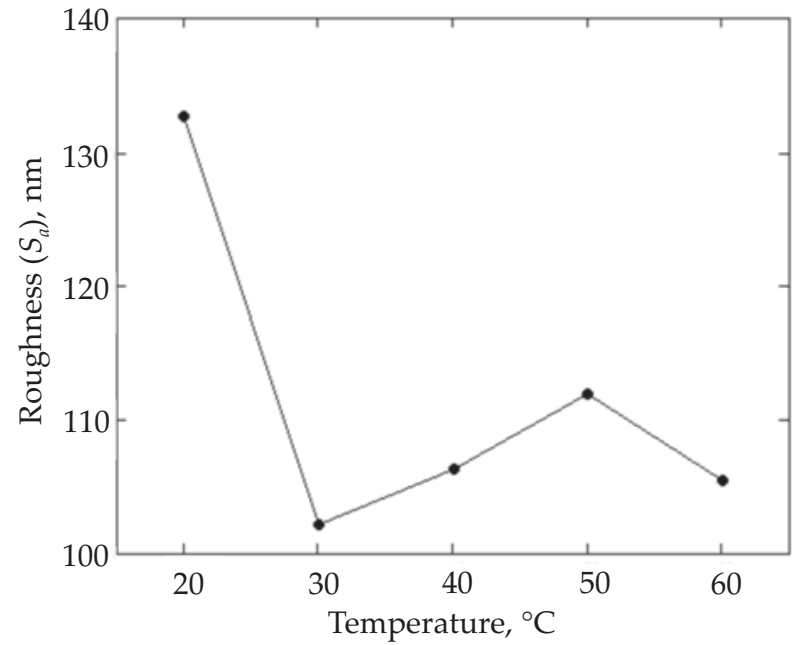

Fig. 5. Influence of temperature on the surface roughness of LDPE sample after a tenfold recirculation process: a) root-mean-square roughness $S_{q}$ b) average roughness $S_{a}$

a)

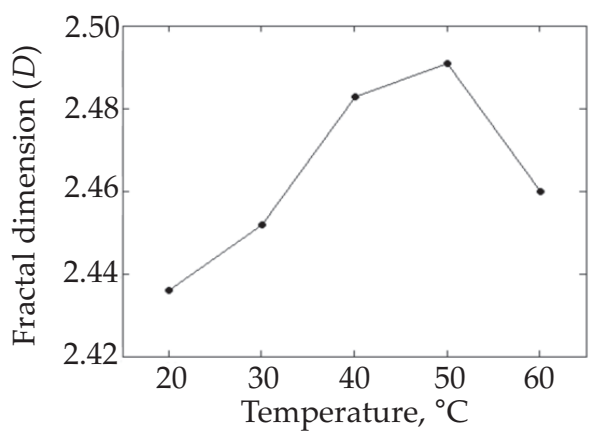

b)

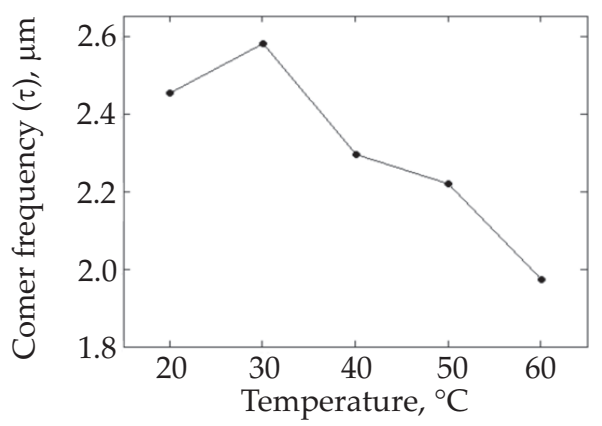

c)

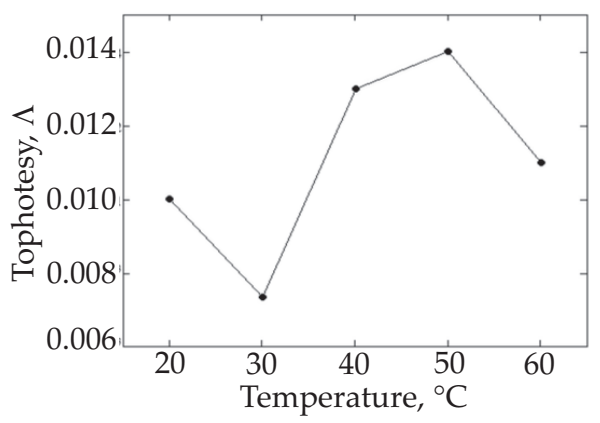

Fig. 6. Changes in geometrical structure of LDPE as a function of temperature: a) fractal dimension, b) corner frequency, c) topothesy
Figure $6 \mathrm{~b}$ demonstrates that unlike fractal dimension, corner frequency $\tau_{c}$ rapidly goes up from $2.4 \mu \mathrm{m}$ to about $2.6 \mu \mathrm{m}$, when temperature is raised from $20^{\circ} \mathrm{C}$ to $30^{\circ} \mathrm{C}$, but after that point it steadily falls down to about $2.0 \mu \mathrm{m}$ at $60^{\circ} \mathrm{C}$. Bearing in mind that corner frequency is also referred to as the correlation length, the range in which the surface remains self-similar is the largest at $30^{\circ} \mathrm{C}$. Shown in Fig. 6c, plot of topothesy behaves in a different manner, since it approaches two extreme values in a studied range of temperatures. At $30^{\circ} \mathrm{C}$ topothesy takes the lowest value, whereas at $50{ }^{\circ} \mathrm{C}$ - the highest, which suggests these two temperatures as thresholds for some structural changes within the material.

Another trend can be seen in Fig. 7a, where a plot of a pseudo-topothesy $v s$. temperature is presented. Here, the plot initially goes downward, reaches its minimum at $30{ }^{\circ} \mathrm{C}$, and then asymptotically saturates at 0.016 . Unfortunately, even though the meanings of topothesy and pseudo-topothesy are well known, their strict interpretation remains ambiguous. Changes in surface anisotropy ratio $S_{t r}$ shown in Fig. $7 \mathrm{~b}$ indicate that in the beginning (at room temperature) the surface is moderately anisotropic with $S_{t r}$ close to 0.4 . With temperature raised to $50^{\circ} \mathrm{C}$, however, the surface undergoes re-arrangement process towards more isotropic structure which is associated with increasing anisotropy ratio. At $50{ }^{\circ} \mathrm{C} S_{t r}$ reaches its maximum value equal to 0.6 , and beyond that temperature, the surface turns the opposite transition becoming highly anisotropic with $S_{t r}$ equal to 0.3 at $60^{\circ} \mathrm{C}$.

\section{DSC results}

DSC thermogram of rLDPE is shown in Fig. 8. In a glassy state, polyethylene naturally takes a semicrystalline structure [26], and keeps it up to $28^{\circ} \mathrm{C}$. Above that temperature, however, the process of mixing of an amorphous and crystalline phases is initiated. From the anal- 
a)

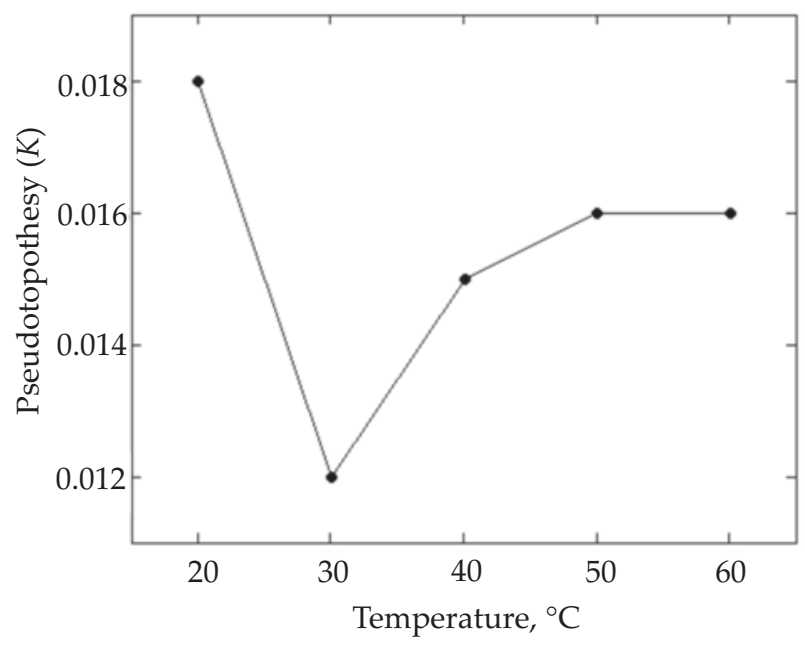

b)

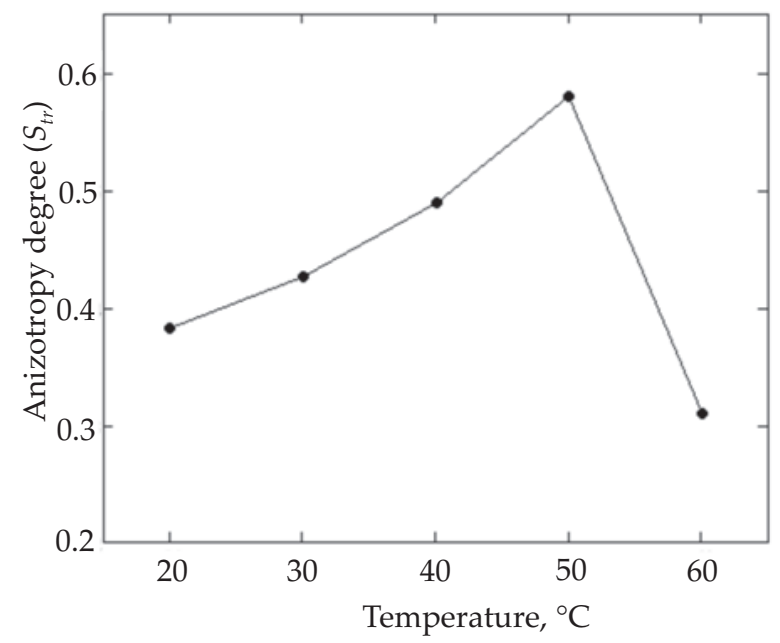

Fig. 7. The influence of temperature on structural parameters of LDPE sample after a tenfold recirculation process: a) pseudo-topothesy, b) anisotropy ratio

ysis of the thermogram in Fig. 8, it can be seen that this phenomenon in LDPE subjected to a tenfold recirculation begins at $30^{\circ} \mathrm{C}$ (first maximum), but slows down at around $50{ }^{\circ} \mathrm{C}$. Once the temperature exceeds $50{ }^{\circ} \mathrm{C}$, fast process of melting of crystallites takes place. The above observations agree well with those obtained from fractal analysis of AFM data (Fig. 6). In addition, DSC results also confirm the statements given by the changes in the anisotropy ratio seen in Fig. $7 \mathrm{~b}$. Obtained $S_{t r}$ values exhibit moderate anisotropy of the polymer at near-room temperature which is associated with its distinct semicrystalline structure in a glassy state that is partly due to the processing operations (clearly separated crystalline and amorphous phases). On the other hand, Fig. $7 \mathrm{~b}$ also shows that in the range from $30^{\circ} \mathrm{C}$ to $50{ }^{\circ} \mathrm{C}$, the sample became isotropic, which is an evidence for the occurrence of a process of mixing/joining of these two phases.

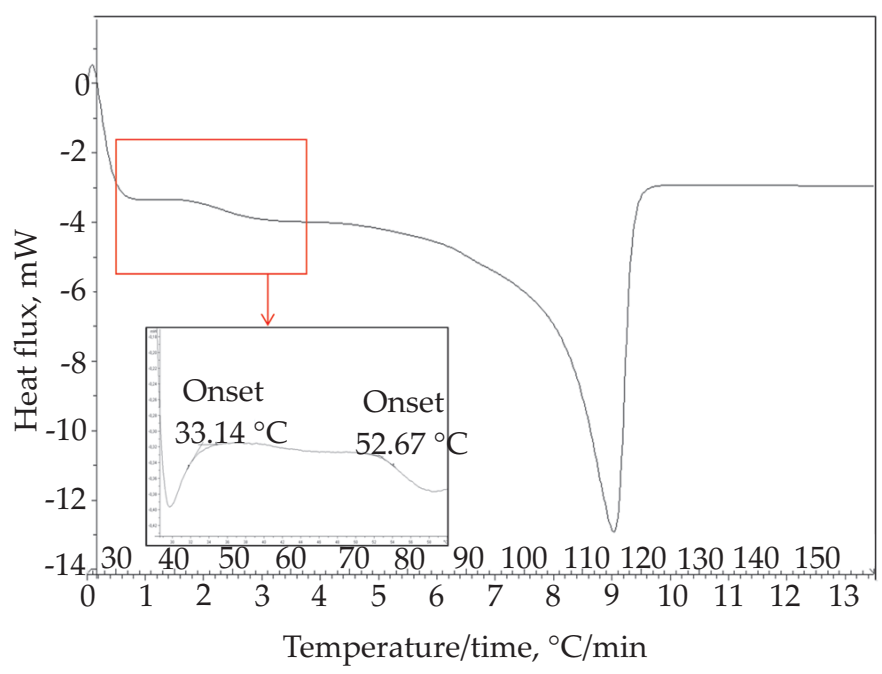

Fig. 8. Thermogram of LDPE sample after tenfold recirculation

\section{CONCLUSIONS}

For the very first time, this work demonstrates applicability of the fractal analysis to study temperature-induced changes in geometrical structure of surfaces of polymeric materials. Numerical methods exploring the autocorrelation function and fractal properties of data series of surface heights probed by AFM are promising tools which might help in improving the properties of the polymers. Obtained results clearly suggest that fractal parameters are equally sensitive to changes in surface topography and corresponding changes in the inner structure of the material subjected to the heat treatment. Analysis of AFM data gives deeper insight into results that were also complimented using various calorimetric techniques, more specifically the DSC.

\section{REFERENCES}

[1] "Metrology and Properties of Engineering Surfaces"(Eds. Mainsah E., Greenwood J.A., Chetwynd D.G.), Kluwer Academic Publishers Inc., Norwell, MA 2001.

[2] Ahmad A.L., Idrus N.F., Abd Shukor S.R.: Journal of the American Ceramamic Society 2006, 89, 1694. http://dx.doi.org/10.1111/j.1551-2916.2006.00964.x

[3] Hanaor D.A.H., Gan Y., Einav I.: Geotechnique Letters 2013, 3, 52. http://dx.doi.org/10.1680/geolett.13.016

[4] Komvopoulos K.: Journal of Adhesion Science and Technology 2003, 17, 477. http://dx.doi.org/10.1163/15685610360554384

[5] Santacruz-Vázquez V., Santacruz-Vázquez C., WeltiChanes J. et al.: Revista Mexicana de Ingeniería Química 2008, 7, 55.

[6] Kowalik-Klimczak A., Bednarska A., Grądkowski M., Gierycz P.: Polimery 2016, 61, 339. 
http://dx.doi.org/10.14314/polimery.2016.339

[7] Mouginot R., Sarikka T., Ehrnstén U., Hänninen H.: Materials Research Express 2019, 6, 8. http://dx.doi.org/10.1088/2053-1591/aafeaf

[8] Deng X., Xiong F., Li X.etal.:Journal of Nanobiotechnology 2018, 16, 102.

http://dx.doi.org/10.1186/s12951-018-0428-0

[9] Smijs T., Galli F., van Asten A.: Forensic Chemistry 2016, 2, 93.

http://dx.doi.org/10.1016/j.forc.2016.10.005

[10] Dmowska-Jasek P., Rzymski W.M., Smejda-Krzewicka A.: Polimery 2016, 61, 189. http://dx.doi.org/10.14314/polimery.2016.189

[11] Klat D., Karimi-Varzaneh H.A., Lacayo-Pineda J.: Polymers 2018, 10, 510. http://dx.doi.org/10.3390/polym10050510

[12] Fardin N., Stephansson O., Jing L.: International Journal of Rock Mechanics \& Mining Sciences 2001, 38, 659.

[13] Bhushan B.: "Nanotribology and Nanomechanics: An Introduction". Springer-Verlag Berlin, Heidelberg 2008.

[14] Jouini N., Gautier A., Revel P. et al.: International Journal of Surface Science and Engineering 2009, 3 (4). http://dx.doi.org/10.1504/IJSURFSE.2009.027418

[15] Dallaeva D., Talu S., Stach S. et al.: Applied Surface Science 2014, 312 C, 81. http://dx.doi.org/10.1016/j.apsusc.2014.05.086

16] Talu S., Stach S., Lainović T. et al.: Applied Surface Science 2015, 330, 20. http://dx.doi.org/10.1016/j.apsusc.2014.12.120

[17] Kulesza S., Bramowicz M.: Applied Surface Science 2014, 293, 196. http://dx.doi.org/10.1016/j.apsusc.2013.12.132

[18] Ibaseta N., Biscans B.: Powder Technology 2010, 203, 206.

http://dx.doi.org/10.1016/j.powtec.2010.05.010

[19] Charkaluk E., Bigerelle M., Iost A.: Engineering Fracture Mechanics 1998, 61, P119.

http://dx.doi.org/10.1016/S0013-7944(98)00035-6
[20] Staszczuk P., Błachnio M., Kowalska E., Sternik D.: Journal of Thermal Analysis and Calorimetry 2006, 86, 51. http://dx.doi.org/10.1007/s10973-006-7582-6

[21] ISO 4287:1997 Geometrical product specifications (GPS) - surface texture: profile method - terms, definitions and surface texture parameters.

[22] Mandelbrot B.B., Blumen A.: "Fractal geometry: what is it, and what does it do?" Proceedings of the Royal Society London A 1989, 423 (1864). http://dx.doi.org/10.1098/rspa.1989.0038

[23] Wu H.J.: Chaos Solitons \& Fractals 2002, 13, 1791.

[24] Bramowicz M., Kulesza S.: Solid State Phenomena 2013, 203-204, 315.

http://dx.doi.org/10.4028/www.scientific.net/SSP.203204.315

[25] Bramowicz M., Kulesza S., Czaja P., Maziarz W.: Archives of Metallurgy and Materials 2014, 59, 451. http://dx.doi.org/10.2478/amm-2014-0075

[26] Bramowicz M., Kulesza S., Mrozek G.: Technical Sciences 2014, 17, 371.

[27] Stout K.J., Sullivan P.J., Dong W.P.: “The development of methods for the characterization of roughness in three dimensions", Publication no EUR15178EN of the Commission of the European Communities Dissemination of Scientific and Technical Knowledge Unit Directorate General Information Technologies and Industries and Telecommunications, University of Birmingham Edgbaston, Birmingham 1993, B152 TT.

[28] Wunderlich B.: "The Basis of Thermal Analysis" in "Thermal Characterization of Polymeric Materials" (Ed. Turi E.A.), Academic Press, 1997.

[29] Balcerowiak W.: Polimery 1998, 43, 373.

[30] Balcerowiak W., Maciejewska H.: Polimery 1994, 39, 626.

[31] Czaja K., Białek M.: Polimery 2002, 47, 685.

[32] PN-EN ISO 11357-1:2016-11 Plastics - Differential scanning calorimetry (DSC) - Part 1: General principles.

Received 7 V 2019.

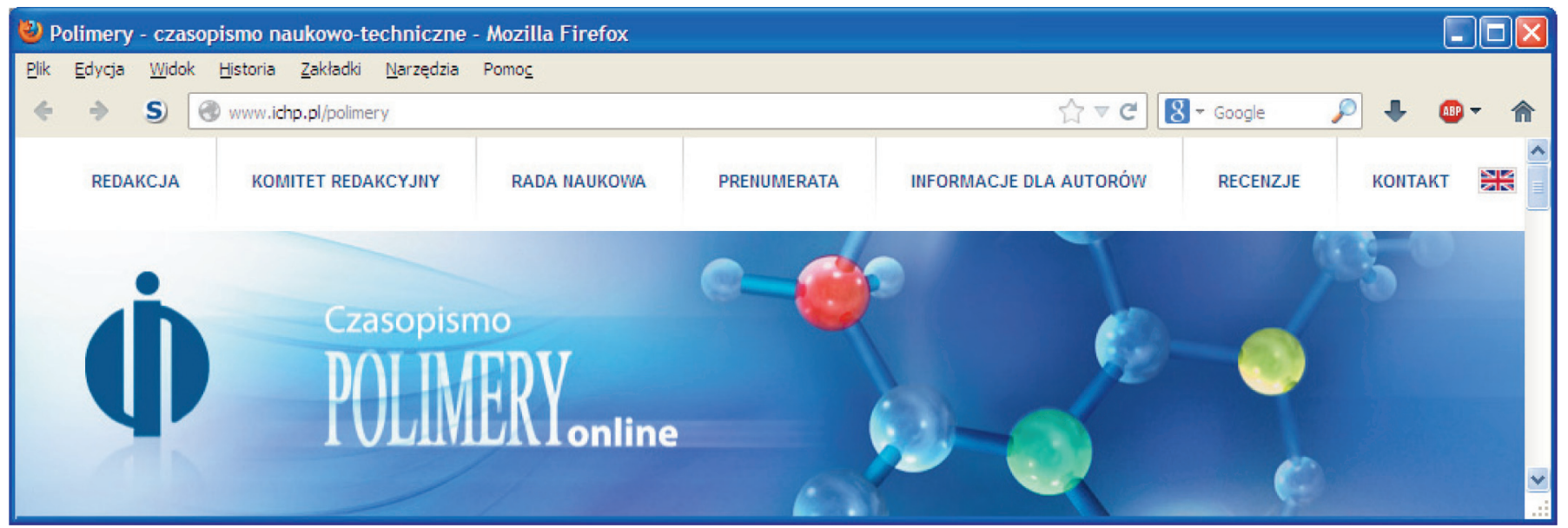

